\title{
Optimasi Kapasitas Baterai Dinamis Asam Timbal (Redox Flow Battery)
}

\author{
Nur Khairati, Ahmad A. Amirullah, Riky D. Susilo, Yofinda E. Setiawan, M. Yusmawanto, Masruroh, \\ Cholisina A. Perwita, Muhammad Ghufron, Kurriawan Budi Pranata
}

\begin{abstract}
Baterai dinamis atau yang dikenal dengan Redox Flow Battery (RFB) merupakan jenis baterai sekunder yang banyak dikembangkan karena kemampuannya untuk menyimpan energi dalam jumlah besar. Pada penelitian ini, dikembangkan baterai dinamis berbasis asam timbal dimana timbal $(\mathbf{P b})$ dan timbal dioksida $\left(\mathrm{PbO}_{2}\right)$ digunakan sebagai elektroda baterai dengan luas permukaan pelat $(13,5 \times 7,5) \mathrm{cm}^{2}$. Baterai dinamis asam timbal diuji sehingga diketahui pengaruh perbedaan konsentrasi $\mathrm{H}_{2} \mathrm{SO}_{4}$ terhadap karakteristik baterai. Variasi konsentrasi $\mathrm{H}_{2} \mathrm{SO}_{4}$ yang digunakan adalah $20 \%$ dan $30 \%$. Pengujian siklus pengisian-pengosongan dilakukan dengan alat BMS (Battery Management System) yaitu Turnigy Accucell-6 sebanyak 3 siklus dengan arus pembebanan $1 \mathrm{~A}$. Berdasarkan hasil penelitian, kapasitas baterai dinamis asam timbal meningkat dengan meningkatnya konsentrasi $\mathrm{H}_{2} \mathrm{SO}_{4}$. Baterai dinamis asam timbal 30\% menghasilkan kapasitas rata-rata tertinggi yaitu 4.657 $\mathrm{mAh}$ dengan efisiensi rata-rata $82,90 \%$. Baterai dinamis 30\% diuji masing-masing 1 siklus dengan variasi waktu pengisian untuk mengetahui waktu pengisian optimal baterai. Variasi waktu pengisian yang digunakan adalah 0,$5 ; 1 ; 1,5 ; 2 ; 2,5$ jam serta pengisian hingga titik cut-off . Hasil penelitian menunjukkan bahwa kapasitas baterai meningkat dengan meningkatnya waktu pengisian baterai, dengan efisiensi tertinggi baterai dinamis $30 \%$ adalah pada pengisian 2 jam.
\end{abstract}

Kata Kunci- Baterai Asam Timbal, Efisiensi Baterai, $\mathrm{H}_{2} \mathrm{SO}_{4}$, Kapasitas, RFB.

Paper dikirim tanggal 13 September 2018. Penelitian ini terselenggara atas kerjasama universitas brawijaya dengan universitas kanjuruhan malang..

Nur Khairati adalah alumni Jurusan Fisika, FMIPA Universitas Brawijaya; nur.khairati65@gmail.com

Ahmad A. Amirullah adalah alumni Jurusan Fisika, FMIPA Universitas Brawijaya.

Riky D.Susilo adalah alumni Jurusan Fisika, FMIPA Universitas Brawijaya.

Yofinda E. Setiawan adalah alumni Jurusan Fisika, FMIPA Universitas Brawijaya.

M. Yusmawanto adalah alumni Jurusan Fisika, FMIPA Universitas Brawijaya.

Masruroh adalah dosen jurusan Fisika, FMIPA Universitas Brawijaya

Cholisina A. Perwita adalah dosen Jurusan Fisika, FMIPA Universitas Brawijaya

Muhammad Ghufron adalah dosen Jurusan Fisika, FMIPA

Universitas Brawijaya; email mghufron@ub.ac.id

Kurriawan Budi Pranata adalah dosen Program Studi Pendidikan

Fisika, Uiversitas Kanjuruhan Malang 65148 ; kurriawan@ gmail.com

\section{PENDAHULUAN}

$\mathrm{B}$ aterai merupakan komponen yang dapat menyimpan dan menghasilkan energi listrik melalui konversi reaksi kimia (reduksi-oksidasi). Baterai terdiri dari sepasang elektroda dan elektrolit [1]. Secara garis besar baterai dibedakan menjadi baterai primer yang tidak dapat diisi ulang dan baterai sekunder yang dapat diisi ulang atau bersifat rechargeable [2]. Baterai dinamis merupakan salah satu jenis baterai sekunder dimana material aktif baterai berada dalam wadah terpisah. Baterai dinamis memiliki kelebihan yaitu dalam meningkatkan kapasitas atau daya baterai dapat dilakukan dengan memodifikasi salah satu komponennya (sel atau chamber) [3]. Baterai dinamis atau redox flow battery (RFB) dikembangkan sebagai penyimpan energi skala besar pada pembangkit listrik terbarukan untuk stabilisasi listrik [4,5]. Pembangkit listrik terbarukan merupakan alternatif penghasil energi listrik mengingat ketersediaan sumber listrik tak terbarukan yang semakin menipis, sementara kebutuhan akan energi listrik terus meningkat. Pembangkit listrik terbarukan sangat bergantung pada kondisi alam, salah satunya adalah sel surya yang bergantung pada intensitas cahaya matahari yang diterimanya. Energi listrik yang dihasilkan oleh sel surya pada siang hari disimpan oleh baterai untuk kemudian digunakan pada kondisi intensitas matahari rendah atau pada malam hari.

Elektrolit pada baterai dinamis berada dalam chamber, sementara elektroda berada dalam sel. Elektrolit dialirkan menggunakan pompa melewati sel, sehingga reaksi redoks terjadi pada bagian sel baterai [5]. Baterai dinamis digolongkan menjadi baterai dinamis elektrolit ganda dan baterai dinamis elektrolit tunggal. Baterai dinamsi elektrolit ganda menggunakan dua jenis elektrolit yang berbeda sehingga diperlukan komponen membran pemisah ion, sementara baterai dinamis elektrolit tunggal hanya menggunakan satu jenis elektrolit [6]. Baterai dinamis elektrolit tunggal memiliki beberapa kelebihan karena pada baterai dinamis elektrolit tunggal, tidak diperlukan membran pemisah ion sehingga pembuatannya menjadi lebih sederhana dan memerlukan biaya lebih murah, beberapa permasalahan baterai dinamis elektrolit ganda pada membran tidak perlu lagi dikhawatirkan serta reaksi kimia larutan terjadi secara langsung [7].

Baterai berbasis asam timbal merupakan salah satu jenis baterai yang dikembangkan sebagai baterai dinamis. Zhang (2011) membandingkan performa 
baterai dinamis berbasis asam timbal, dimana baterai dinamis yang diuji menunjukkan performa sebaik baterai konvensional [8]. Pada 2017, Ghufron dan Kurriawan membandingkan baterai dinamis asam timbal dengan baterai konvensional (aki). Baterai dinamis yang diuji memiliki performa yang lebih baik dari aki, ditunjukkan oleh efisiensi energi baterai dinamis sebesar $67,9 \%$, sementara aki memiliki efisiensi energi 35,5\% [9].

Baterai asam timbal yang salah satunya aki terdiri atas elektroda negatif (anoda) $\mathrm{Pb}$ dan elektroda positif (katoda) $\mathrm{PbO}_{2}$ dengan elektrolit larutan asam sulfat $\left(\mathrm{H}_{2} \mathrm{SO}_{4}\right)$. Pada proses pengosongan baterai, ion $\mathrm{HSO}_{4}$ bergerak menuju elektroda negatif membentuk ion $\mathrm{H}^{+}$ dan $\mathrm{PbSO}_{4}$. Pada elektroda positif, timbal dioksida bereaksi dengan elektrolit membentuk kristal $\mathrm{PbSO}_{4}$ dan air. Kedua elektroda membentuk timbal sulfat yang merupakan isolator, sementara elektrolit mengalami penurunan konsentrasi selama proses pengosongan [10]. Reaksi kimia yang terjadi dapat dituliskan dalam persamaan setengah reaksi berikut :

$$
\mathrm{Pb}+\mathrm{H}_{2} \mathrm{SO}_{4} \leftrightarrow \mathrm{PbSO}_{4}+2 \mathrm{H}^{+}+2 e
$$

$\mathrm{Pb}$ merupakan elektroda negatif karena dihasilkan elektron pada proses pengosongan baterai.

$$
\mathrm{PbO}_{2}+2 \mathrm{H}^{+}+\mathrm{H}_{2} \mathrm{SO}_{4}+2 e \leftrightarrow \mathrm{PbSO}_{4}+2 \mathrm{H}_{2} \mathrm{O}
$$

Kedua setangah reaksi diatas dapat dituliskan secara lengkap [11] yaitu :

$$
\mathrm{Pb}+\mathrm{PbO}_{2}+2 \mathrm{H}_{2} \mathrm{SO}_{4} \leftrightarrow 2 \mathrm{PbSO}_{4}+2 \mathrm{H}_{2} \mathrm{O}
$$

Elektrolit merupakan salah satu parameter yang mempengaruhi performa baterai. Pada 2015, Akbar dan Lapanporo membandingkan performa baterai $\mathrm{Cu}-\mathrm{Zn}$ dengan jenis dan konsentrasi elektrolit yang berbeda. Konsentrasi elektrolit yang berbeda menghasilkan performa baterai yang berbeda pula. Pada penggunaan elektrolit $\mathrm{H}_{2} \mathrm{SO}_{4}$, dihasilkan tegangan baterai maksimum pada konsentrasi $\mathrm{H}_{2} \mathrm{SO}_{4} 29,134 \%$, dimana nilai ini sesuai dengan standar konsentrasi $\mathrm{H}_{2} \mathrm{SO}_{4}$ yang digunakan pada aki yaitu antara 29-32\% [12].

Pada penelitian ini, untuk mengetahui karakteristik baterai dinamis asam timbal yang dipengaruhi oleh perbedaan konsentrasi $\mathrm{H}_{2} \mathrm{SO}_{4}$, penulis mengembangkan baterai dinamis asam timbal elektrolit tunggal dengan 2 variasi konsentrasi $\mathrm{H}_{2} \mathrm{SO}_{4}$. Sistem baterai dengan performa yang lebih baik kemudian diuji dengan variasi waktu pengisian untuk mengetahui kapasitas optimum baterai dinamis asam timbal.

\section{METODE PENELITIAN}

Bagian utama dari baterai asam timbal pada penelitian ini adalah sel baterai, chamber dan pompa serta material aktif baterai. Material aktif baterai adalah elektroda dan elektrolit. Elektroda yang digunakan pada sistem baterai adalah pelat $\mathrm{Pb}$ dan $\mathrm{PbO}_{2}$ dengan luas permukaan $(13,5 \times 7,5) \mathrm{cm}^{2}$, sementara elektrolit yang digunakan adalah $\mathrm{H}_{2} \mathrm{SO}_{4}$ dengan 2 variasi konsentrasi yaitu $20 \%$ dan $30 \%$. Elektroda positif dan negatif berada dalam sel baterai dengan jarak antar pelat elektroda adalah $3 \mathrm{~mm}$ dan dipisahkan oleh membran separator. Sel baterai dan chamber dihubungkan oleh selang, dimana pada ujung selang dalam chamber dihubungkan pada pompa sehingga elektrolit dialirkan dari chamber menuju sel baterai. Elektroda di dalam sel baterai berada pada keadaan tercelup dalam elektrolit $\mathrm{H}_{2} \mathrm{SO}_{4}$ dengan volume total elektrolit pada baterai dinamis adalah $400 \mathrm{ml}$. Laju aliran elektrolit adalah 9 ml per menit.

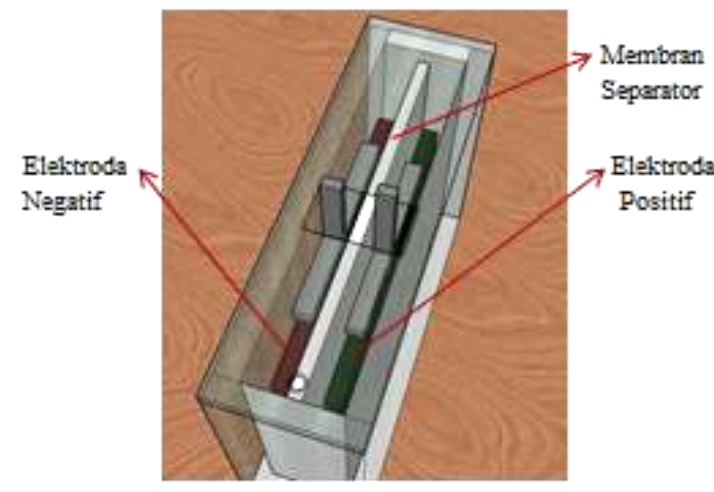

Gambar 1. Susunan elektroda dan separator dalam sel baterai

Pengujian karakteristik (pengisian-pengosongan) baterai dilakukan dengan alat BMS (Battery Management System) yaitu Turnigy Accucell-6. Perekaman data arus, tegangan dan kapasitas terhadap waktu dari proses pengujian baterai dilakukan dengan perangkat lunak yang telah terintegrasi pada laptop dan alat Turnigy Accucell-6 yaitu ChargeMaster2.02. Pengujian pengisian-pengosongan baterai dilakukan sebanyak 3 siklus dengan arus sebesar 1 A untuk masing-masing baterai dinamis asam timbal dengan variasi konsentrasi $\mathrm{H}_{2} \mathrm{SO}_{4}$. Pengujian pengisianpengosongan baterai asam timbal dengan Turnigy Accucell-6 memiliki batas tegangan maksimum pengisian $2,41 \mathrm{~V}$ dan tegangan minimum pengosongan 1,81 V. Pengujian baterai dinamis dengan variasi waktu pengisian dilakukan sebanyak 1 siklus untuk masingmasing variasi waktu dengan arus pembebanan $1 \mathrm{~A}$.

\section{HASIL DAN PEMBAHASAN}

\section{A. Karakteristik Pengisian-Pengosongan}

Reaksi spontan antara elektroda $\mathrm{Pb}-\mathrm{PbO}_{2}$ dan elektrolit $\mathrm{H}_{2} \mathrm{SO}_{4}$ pada baterai asam timbal terjadi pada proses pengosongan. Reaksi kebalikan dari reaksi spontan tersebut dapat terjadi dengan pemberian energi pada baterai yang kita kenal dengan istilah pengisian baterai (charging). Pada proses pengisian, tegangan baterai mengalami kenaikan yang menunjukkan bahwa terjadi penyimpanan energi listrik pada baterai. Berdasarkan gambar 2, tegangan baterai pada proses pengisian naik secara signifikan dari nilai tegangan baterai tanpa pembebanan menuju tegangan awal pengisian yang terjadi karena adanya hambatan dalam baterai. Tegangan baterai kemudian mengalami kenaikan hingga 2,41 V dan kemudian konstan pada tegangan 2,41 V hingga proses pengisian baterai selesai. Pada tegangan baterai konstan $2,41 \mathrm{~V}$, arus pengisian 
baterai yang semula konstan 1 A mengalami penurunan hingga arus minimum 0,09 A. Proses pengisian baterai berhenti atau selesai ketika arus minimum tersebut dicapai, dengan kata lain tidak ada lagi muatan yang dapat disimpan oleh baterai.

Pada proses pengosongan, tegangan baterai mengalami penurunan dari nilai tegangan baterai tanpa pembebanan setelah proses pengisian menuju tegangan awal pengosongan baterai yang disebabkan oleh adanya hambatan dalam baterai. Tegangan baterai kemudian mengalami penurunan perlahan yang menunjukkan bahwa baterai mengeluarkan energi yang semula disimpannya. Arus pengosongan baterai adalah konstan 1 A. Pengosongan baterai berhenti atau selesai ketika tegangan cut-off baterai sebesar 1,81 V telah dicapai.

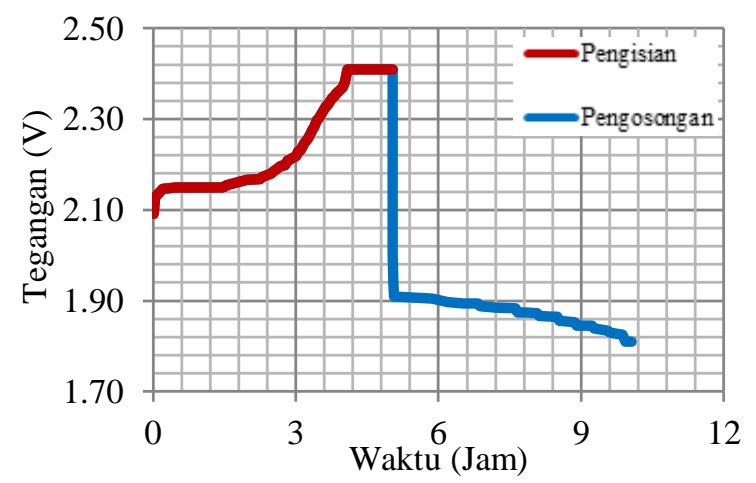

Gambar 2. Grafik tegangan terhadap waktu 1 siklus pengisianpengosongan baterai dinamis asam timbal

\section{B. Karakteristik Tegangan Baterai berdasarkan Perbedaan Konsentrasi $\mathrm{H}_{2} \mathrm{SO}_{4}$}

Berdasarkan persamaan Nernst, tegangan baterai berubah menuju arah lebih positif dengan bertambahnya konsentrasi $\mathrm{H}_{2} \mathrm{SO}_{4}$ [13]-[14]. Gambar 3 berikut menunjukkan grafik tegangan terhadap waktu untuk 3 siklus pengisian-pengosongan baterai dinamis asam timbal.

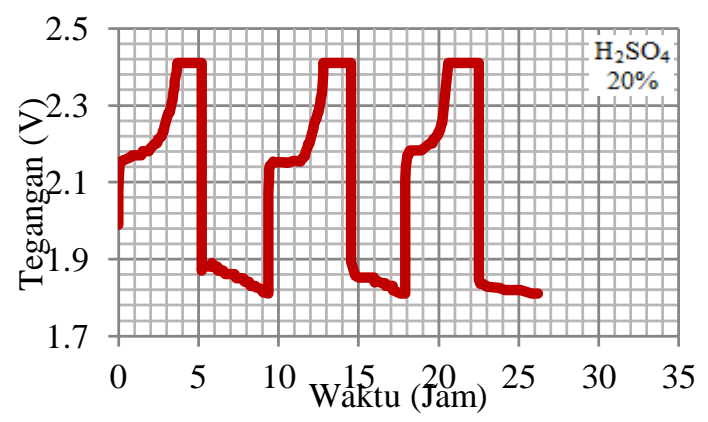

(a)

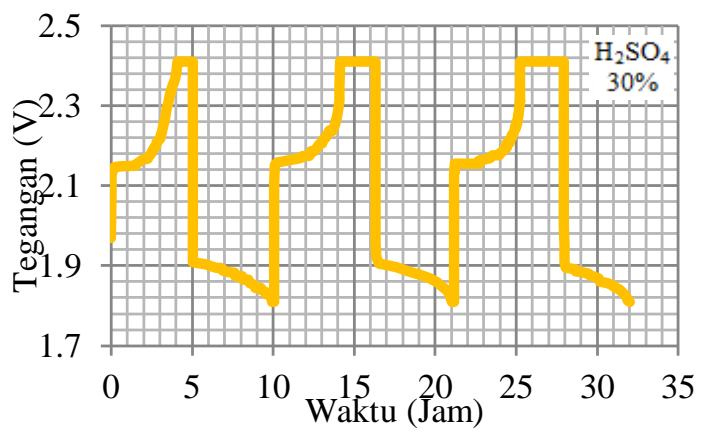

(b)

Gambar 3. Grafik tegangan terhadap waktu 3 siklus pengisianpengosongan baterai dinamis asam timbal dengan 2 variasi konsentrasi $\mathrm{H}_{2} \mathrm{SO}_{4}$ (a) $20 \%$ dan (b) $30 \%$

Berdasarkan Gambar 3 tersebut diketahui bahwa baterai dengan konsentrasi $\mathrm{H}_{2} \mathrm{SO}_{4}$ yang lebih tinggi memiliki durasi pengisian-pengosongan yang lebih lama. Selain itu, tegangan awal pengisian maupun pengosongan lebih tinggi pada baterai dengan konsentrasi $\mathrm{H}_{2} \mathrm{SO}_{4}$ yang lebih tinggi. Ketiga siklus pengisian-pengosongan baterai menunjukkan karakteristik yang serupa sehingga diketahui bahwa baterai dinamis asam timbal yang telah diuji bersifat rechargeable. Tegangan pengosongan baterai dinamis asam timbal meningkat dengan meningkatnya konsentrasi $\mathrm{H}_{2} \mathrm{SO}_{4}$ yang digunakan. Baterai dinamis $20 \%$ dengan arus beban 1 A memiliki tegangan dan waktu pengosongan yang menurun secara signifikan dari siklus 1 hingga siklus 3 , sementara tegangan pengosongan baterai dinamis $30 \%$ memiliki kecenderungan menurun yang tidak begitu signifikan. Hal ini menunjukkan bahwa baterai dinamis $20 \%$ mengalami penurunan performa yang lebih cepat dibandingkan baterai dinamis $30 \%$.

\section{Karakteristik Kapasitas Baterai berdasarkan Perbedaan Konsentrasi $\mathrm{H}_{2} \mathrm{SO}_{4}$}

Kapasitas atau penyimpanan energi baterai dinyatakan dalam satuan Ampere-hours (Ah) pada nilai tegangan dan arus tertentu [15]. Kapasitas baterai menunjukkan banyaknya muatan listrik yang dapat disimpan maupun dikeluarkan oleh baterai. Kapasitas keluaran (pengosongan) baterai merupakan besaran yang digunakan dalam mendeskripsikan karakteristik baterai. Gambar 3 menunjukkan bahwa semakin tinggi konsentrasi $\mathrm{H}_{2} \mathrm{SO}_{4}$ yang digunakan pada baterai, maka semakin lama waktu pengosongan baterai. Waktu pengosongan baterai sebanding dengan kapasitas baterai dan dengan arus pengosongan konstan $1 \mathrm{~A}$, maka diketahui bahwa kapasitas baterai dinamis asam timbal lebih tinggi pada baterai dengan konsentrasi $\mathrm{H}_{2} \mathrm{SO}_{4}$ yang lebih tinggi pula.

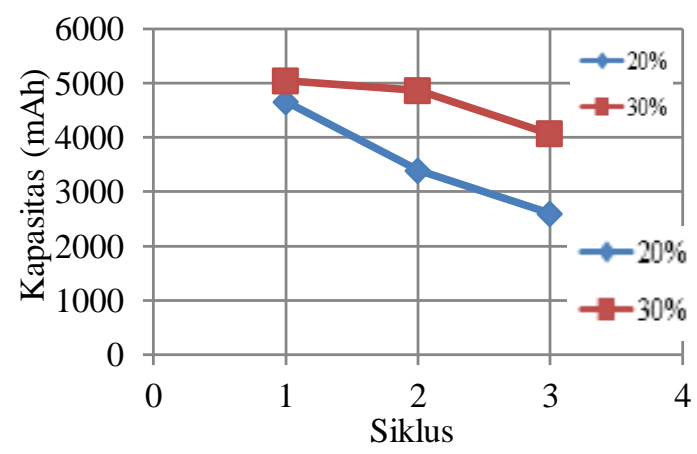

Gambar 4. Grafik kapasitas terhadap waktu 3 siklus pengisianpengosongan baterai dinamis asam timbal dengan 2 variasi konsentrasi $\mathrm{H}_{2} \mathrm{SO}_{4}$ 
Berdasarkan Gambar 4 tersebut, diketahui bahwa kapasitas baterai mengalami penurunan dari siklus 1 hingga siklus 3, yang diakibatkan oleh adanya sisa material $\mathrm{PbSO}_{4}$ yang tidak teruraikan kembali pada proses pengisian baterai. Kapasitas baterai dinamis asam timbal meningkat seiring dengan meningkatnya konsentrasi $\mathrm{H}_{2} \mathrm{SO}_{4}$. Kapasitas rata-rata baterai dinamis $30 \%$ yaitu $4.657 \mathrm{mAh},\left(1 \mathrm{mAh}=10^{-3} \mathrm{Ah}\right)$ lebih tinggi dari kapasitas rata-rata baterai dinamis $20 \%$ yaitu 3.548 mAh.

\section{Kapasitas dan Efisiensi Baterai Dinamis $30 \%$ berdasarkan Variasi Waktu Pengisian}

Baterai dinamis $30 \%$ diuji dengan variasi waktu pengisian sehingga diketahui kapasitas dan efisiensi optimal baterai. Gambar 5 berikut menunjukkan kapasitas yang dihasilkan baterai dinamis 30\% setelah dilakukan pengisian dengan 6 variasi waktu. Berdasarkan gambar 5, kapasitas baterai meningkat dengan meningkatnya waktu pengisian baterai.

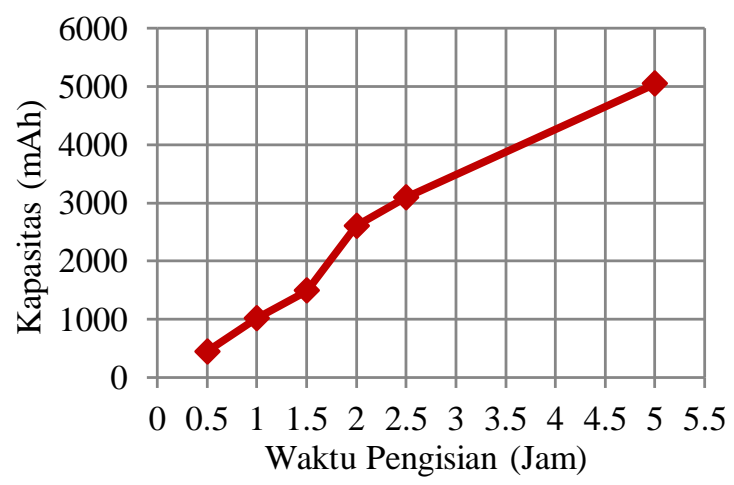

Gambar 5. Kapasitas baterai dinamis $30 \%$ berdasarkan variasi waktu pengisian

Baterai dinamis $30 \%$ dengan waktu pengisian 5 jam memiliki kapasitas tertinggi yaitu 5.042 mAh. Namun demikian, Gambar 6 menunjukkan bahwa efisiensi tertinggi baterai dinamis $30 \%$ diperoleh pada pengisian 2 jam. Kejadian unik diperoleh pada pengisian waktu dengan lama 2 jam dimana diperoleh efisiensi baterai lebih dari $100 \%$. Hal ini terjadi karena pada proses pengosongan sebelumnya berlangsung relatif cepat dan baterai belum benar-benar pada posisi cut-off sehingga masih tersimpan muatan dalam jumlah besar yang tersisa yang kemudian pada proses pengosongan berikutnya mampu menghasilkan muatan tambahan sehingga seolah-olah efisiensi baterai lebih dari $100 \%$.

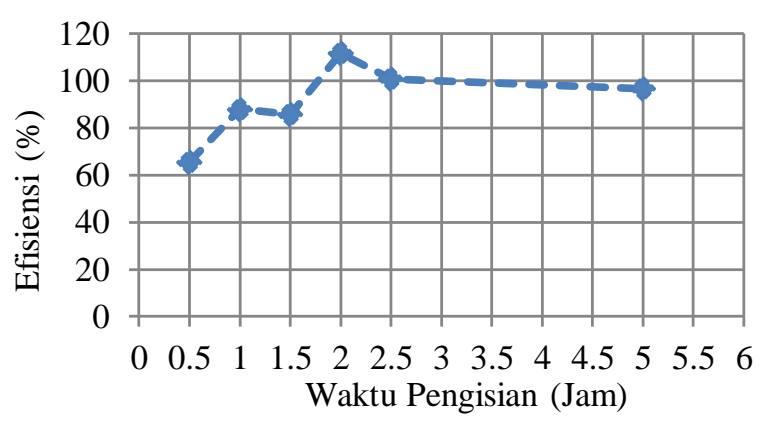

Gambar 6. Efisiensi baterai dinamis $30 \%$ berdasarkan variasi waktu pengisian.

\section{KESIMPULAN}

Baterai dinamis elektrolit tunggal berbasis asam timbal dengan $\mathrm{Pb}_{-} \mathrm{PbO}_{2}\left(13,5 \times\right.$ x 7,5) $\mathrm{cm}^{2}$ sebagai elektroda dan $\mathrm{H}_{2} \mathrm{SO}_{4}$ sebagai elektrolit telah berhasil dikembangkan dengan nilai awal tegangan kerja $\pm 2,15$ $\mathrm{V}$ bergantung pada konsentrasi $\mathrm{H}_{2} \mathrm{SO}_{4}$ yang digunakan. Semakin tinggi konsentrasi $\mathrm{H}_{2} \mathrm{SO}_{4}$ yang digunakan, semakin tinggi tegangan kerja baterai dan semakin tinggi kapasitas baterai yang dihasilkan. Baterai dinamis $30 \%$ dengan efisiensi tertinggi adalah pada pengisian 2 jam dengan kapasitas $2.061 \mathrm{mAh}$. Kemudian perlu proses pengosongan baterai hingga tegangan sangat rendah untuk mengetahui tingkat efisiensi baterai secara lebih akurat.

\section{DAFTAR PUSTAKA}

[1] C. Leonardo, M. Kartawidjaja, W. Alamsyah dan S. Hidayat. (2015, Oktober). Kajian Pengaruh Konsentrasi Elektrolit Terhadap Kinerja Baterai Isi Ulang $\mathrm{PANi} / \mathrm{H}_{2} \mathrm{SO}_{4} / \mathrm{PbO}_{2}$. Prosiding Seminar Nasional Fisika (E-Journal) SNF201, vol. 4. pp. 15-20.

[2] E. Amirudin, C. Sudibyo, dan N. Rohman. (2014, April). Pengaruh Penambahan Vitamin Baterai Vitta-Q terhadap Load Test pada Lead Acid Battery Tipe Liquid Vented 12V 5Ah. Jurnal Ilmiah Pendidikan Teknik Mesin, 2(4).

[3] A. Cunha, J. Martins, N. Rodrigues and F. P. Brito. (2014, October). Vanadium Redox Flow Batteries : A Technology Review. International Journal of Energy Research, 39 (7). pp. 889-918.

[4] Y. K. Zeng, T. S. Zhao, X. L. Zhou, J. Zou, and Y. X. Ren. (2017, March). A hydrogen-ferric ion rebalance cell operating at low hydrogen concentrations for capacity restoration of ironchromium redox flow batteries. Journal of Power Sources, 352. pp. 77-82.

[5] T. Shigematsu. (2011, October). Redox Flow Battery for Energy Storage. SEI Technical Review. (7). pp. 4-13.

[6] J. Martins and F. P. Brito. (2015, ). Vanadium Redox Flow Batteries : A Technology Review. International Journal of Energy Recsearch. 39 (7). pp. 889-918.

[7] D. Pletcher and R. Wills. (2005). A Novel Flow battery-A Lead Acid Battery Based on An Electrolyte with Soluble Lead(II) III. The Influence of Conditions on Battery Performance. Journal of Power Source, 149. pp. 96-102.

[8] C. P. Zhang, S. M. Shark, X. Li, F. C. Walsh, C. N. Zhang and J. C. Jiang. (2011, September). The Performance of a Soluble Lead-Acid Flow Battery and its Comparison to A static LeadAcid Battery. Energy Conversion and Management, 52. pp. 3391-3398.

[9] M. Ghufron dan P. B. Kurriawan. (2017). Energy Efficiency of Zinc-Carbon and Standart Accumulator. Proceedings Book 3. pp. 44-47.

[10] G. J. May, A. Davidson, and B. Monahov. (2018). Lead Batteries for Utility Energy Storage: A Review. Journal of Energy Storage, 15. pp. 145-157.

[11] R. S. Treptow. (2002). The Lead-Acid Battery: Its Voltage in Theory and in Practice. Journal of Chemical Education, 79 (3). pp. 334-338. 
[12] I. A. Akbar dan B. P. Lapanporo. (2015). Optimasi Tegangan Baterai Sel Basah Menggunakan Metode Levenberg-Marquardt. Prisma Fisika, 3 (2). pp. 62-68.

[13] J. Mooney, A. Alaswad, and A. Cruden. (2017). A New pH Phenomenon to Predict Polarity Reversal in Lead-Acid Cells. Energy, 136. pp. 100-109.

[14] D. Pavlov, V. Naidenov, and S. Ruevski. (2006, May). Influence of $\mathrm{H}_{2} \mathrm{SO}_{4}$ Concentration on Lead-Acid Battery Performance $\mathrm{H}$ type and P-type Batteries. Journal of Power Source, 161. pp. 658-665.

[15] G. M. Masters. (2013). Renewable and Efficient Electric Power Systems. San Francisco: John Wiley \& Sons 